\title{
SARS-CoV-2 in Cellular Level: Do We Dominate the Whole Picture and How Can We Intervene?
}

\section{Hücresel Düzeyde SARS-CoV-2: Resmin Tamamına Hakim Miyiz ve Nasıl Müdahale Edebiliriz?}

\author{
๑Muhammed Emin Düz', @Aydın Balcı², @Elif Menekşe' \\ 'Amasya University Sabuncuoğlu Şerefeddin Training and Research Hospital, Division of Clinical Chemistry, Amasya, Turkey \\ ${ }^{2}$ Afyon University School of Medicine Department of Pulmonology, Afyon, Turkey
}

\begin{abstract}
Coronaviruses are a family of viruses present in various animals, and alpha and beta types can infect humans. Human coronavirus varieties settle in different regions of the respiratory tract epithelium, causing disease with varying severity. We conducted a comprehensive academic search to aggregate data and added our own ideas to create a good research article. As a result of many studies carried out in a short time, detailed information was obtained about the entry of the virus into the cell and its cellular cycle. Although vaccination studies are about to come to an end, we do not yet have an agent that provides a definitive treatment that will facilitate millions of people's lives. At this point, humanity needs detailed genetic research, especially on cellular interactions. Because although we think that we are in control of the subject, science is a field that changes daily, and new data are added to it. It is evident that we need marginal ideas for a virus that has affected the whole world, can easily be transmitted by respiratory and droplets, and has destroyed everyday life. This research aims to examine the data we have so far in detail on all of the topics we have mentioned and try to make some suggestions within our knowledge.
\end{abstract}

Keywords: SARS-CoV-2, Covid-19, Coronavirus
Öz

Koronavirüsler, çeşitli hayvanlarda bulunan bir virüs ailesidir ve alfa ve beta türleri insanları enfekte edebilir. Insan koronavirüs çeşitleri, solunum yolu epitelinin farklı bölgelerine yerleşerek değişen şiddette hastalığa neden olur. Verileri toplamak için kapsamlı bir akademik araştırma yaptık ve iyi bir araştırma makalesi oluşturmak için kendi fikirlerimizi ekledik. Kısa sürede yapılan birçok çalışma sonucunda virüsün hücreye girişi ve hücresel döngüsü hakkında detaylı bilgiler elde edildi. Aşılama çalışmaları bitmek üzere olsa da henüz milyonlarca insanın hayatını kolaylaştıracak kesin tedavi sağlayacak bir ajana sahip değiliz. Bu noktada insanlığın özellikle hücresel etkileşimler konusunda detaylı genetik araştırmalara ihtiyacı var. Çünkü konunun kontrolünde olduğumuzu düşünsek de bilim her geçen gün değişen bir alan ve ona yeni veriler ekleniyor. Tüm dünyayı etkilemiş, solunum ve damlacıklarla kolaylıkla bulaşabilen ve günlük yaşamı mahvetmiş bir virüs için marjinal fikirlere intiyacımız olduğu aşikardır. Bu araştırma, bahsettiğimiz tüm konularda bugüne kadar sahip olduğumuz verileri detaylı bir şekilde incelemeyi ve bilgimiz dahilinde bazı önerilerde bulunmayı amaçlamaktadır.

Anahtar Kelimeler: SARS-CoV-2, Covid-19, Koronavirüs

Corresponding (IIletişim): Muhammed Emin DÜZ, Amasya Sabuncuoğlu Şerefeddin Training and Research Hospital, Clinical Biochemistry, Amasya, Turkey 


\section{INTRODUCTION}

The SARS-CoV-2 virus, which emerged in Wuhan, China, in late 2019, was identified as the cause of the Covid-19 disease that swept the world and caused the death of millions. Coronaviruses are a family of viruses present in various animals, and alpha and beta types can infect humans. [1] Human coronavirus varieties settle in different regions of the respiratory tract epithelium, causing disease with varying severity. Although alpha and beta coronaviruses are common in humans, they usually cause mild-severe flu-like upper respiratory tract complaints. However, beta coronaviruses such as MERS-CoV (Middle East respiratory syndrome coronavirus), SARS-CoV (severe acute respiratory syndrome-coronavirus), and SARS-CoV-2 (severe acute respiratory syndrome coronavirus-2) are less common in humans, but more deadly. ${ }^{[2]}$ The three viruses mentioned are believed to be transmitted to humans by bats and other intermediate mammals. ${ }^{[3]}$ Like other coronaviruses, SARS-CoV-2 is a genome close to $30 \mathrm{~kb}$ long; this was similar to $80 \%$ with SARS-CoV, 50\% with MERS-CoV, and more bat-associated coronaviruses (88\% bat-SL-CoVZC45 and bat-SL-CoVZXC21, 93\% with RaTGT13) (Figure 1). The first $2 / 3$ of the genome encodes the replicasetranscriptase complex, and the last third one translates into four structural proteins. Within all viral proteins, the replicase-transcriptase complex is the only protein directly translated from the genome. ORF1a and ORF1b encode two polyproteins ( $p p 1 a$ and $p p 1 b)$ that are spontaneously processed to grant 16 non-structural proteins (Figure 2). Structural proteins are expressed from spike (S), envelope $(\mathrm{E})$, membrane $(\mathrm{M})$, nucleocapsid $(\mathrm{N})$, and other auxiliaries subgenomic mRNAs. ${ }^{[4]}$

\section{Cellular Adhesion}

SARS-CoV-2, an enveloped positive-sense single-stranded RNA virus, uses glycoprotein spikes for receptor recognition and membrane fusion to initiate infection. ${ }^{[5]}$ In mature viruses, the spike protein exists as a trimer with the $\mathrm{S1}$ head attached to the three receptors that sit atop the S2 stalk. The S1 subunit of the coronavirus spike glycoprotein contains the receptor-binding domain (RBD) that binds to the peptidase domain (PD) of host cell angiotensin-converting enzyme 2 (ACE-2). The RBD frequently alters between a standing-up position for receptor binding and a lying-down position for immune evasion. Simultaneously, the S2

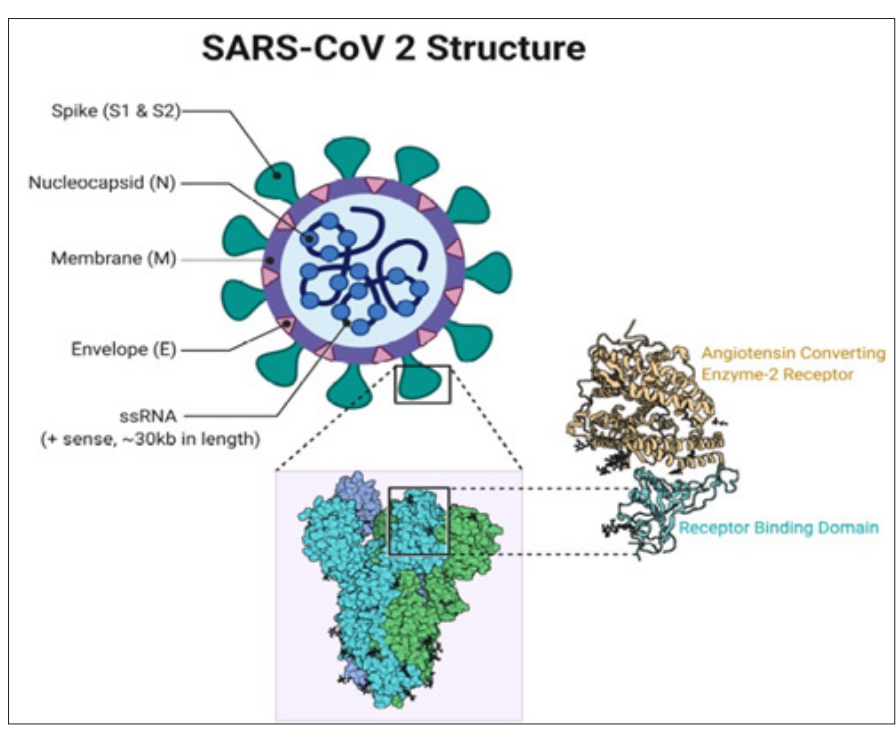

Figure 1. Structure of SARS-CoV 2. From Marco Cascella et al. Features, Evaluation and Treatment Coronavirus (COVID-19).

This file was licensed via the Creative Commons Attribution 4.0 International. (https://creativecommons. org/licenses/by/4.0/deed.en https://commons.wikimedia.org/wiki/File:Struktura_SARS-CoV_2.jpg)

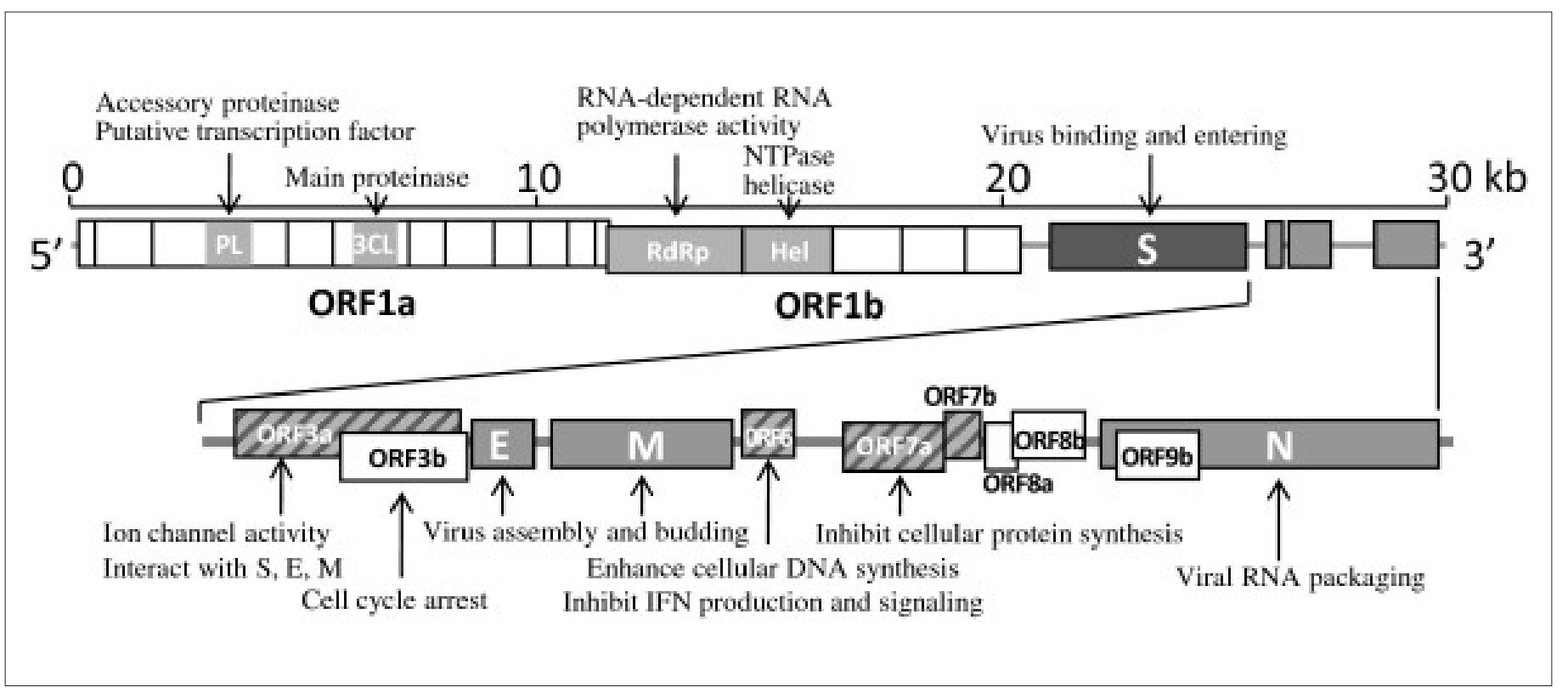

Figure 2. SARS-CoV genome organization. Attribution: Xianchun Tang, Gang Li, Nikos Vasilakis, Yuan Zhang, Zhengli Shi, Yang Zhong, Lin-Fa Wang, and Shuyi Zhang, CC BY 2.0, via Wikimedia Commons.

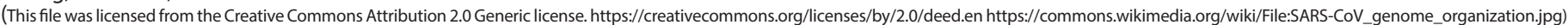


subunit of the spike glycoprotein provides membrane fusion with the host cell. Human ACE-2 is a type 1 membrane glycoprotein that produces angiotensin, which balances blood pressure by vasoconstriction. In coronavirus infections, ACE- 2 is seized by some coronaviruses such as SARS-CoV and SARS-CoV-2 for cell entry purposes. ${ }^{[6]}$ Relative to SARS-CoV, SARS-CoV-2 is believed to bind human ACE-2 more accurately, thereby boosting its chance of human to human transmission. In contrast, SARS-CoV-2, like SARS-CoV, uses host cell transmembrane protease serine 2 (TMPRSS2) to cleave the spike glycoprotein. ${ }^{[7]}$ Moreover, to fuse membranes, the SARS-CoV-2 spike needs to be proteolytically activated at the S1/S2 borderline. Thus, S1 decomposes, and S2 calls upon a theatrical structural change. Proteases that activate this SARS-CoV-2 entry include the cell surface protease TMPRSS2 and cathepsins among lysosomal proteases. The entry also requires the regulation of the $\mathrm{S}$ protein by cellular proteases. This process involves S protein cleavage at the S1/S2 level to allow viral and cellular membrane fusion, a process carried out by the $\$ 2$ subunit. ${ }^{[8]} \mathrm{A}$ highly conserved epitope has been identified to explain crossneutralization with antibodies specific for SARS-CoV-2 S. However, neutralizing antibodies are directed against this $S$ protein.

\section{Viral adhesion theories in the light of new studies}

To date, the whole world knows about SARS-CoV-2 adhesion and cellular entry mechanism but, specifically, restricting the production of phosphatidylinositol 4,5-bisphosphate (PIP2) fetters the fusion of the SARS-CoV-2 envelope with the endolysosomes and viral entry. ${ }^{\left[{ }^{[9]}\right.}$ Additionally, viral entry-related membrane fusion needs a priming step intervened by multiple host proteases, including the lysosome-localized Cathepsin $\mathrm{B} / \mathrm{L}$ and serine proteases of the TMPRSS family. ${ }^{[10]}$ Although some TMPRSS proteases can act at the cell surface, increasing lysosomal pH in TMPRSS2-positive Caco-2 or TMPRSS2-negative HEK293 cells both inhibit SARS-CoV-2 cell entry, suggesting that endolysosomes are the leading entry site for SARS, at least in specific cell types. ${ }^{[1]} \mathrm{A}$ study on the intercellular transmission of misfolded a-Synuclein (a-Syn) fibrils, a cellular process reminiscent of viral infection, demonstrated a mechanism of endocytosis in which cell surface heparan sulfate (HS)-bearing protein assemblages facilitate receptor-mediated uptake. HS is a negative charge-enriched linear polysaccharide molecule that binds to the various membrane and extracellular proteins collectively referred to as heparan sulfate proteoglycans (HSPG). Cell surface HS can act as an anchor to facilitate the endocytosis of many burdens involving SARS-CoV-2 related coronaviruses. ${ }^{[12]}$ Other evidence supporting HS's role in introducing HS mimetic glycan heparin and coronaviruses associated with SARS-CoV-2 Spike and SARS-CoV-2 could guide scientists in terms of the possibility of targeting HS as a Covid-19 therapeutic strategy. ${ }^{[13]}$

The core polymerase assembly proteins structure SARSCoV-2 nsp12-nsp7-nsp8 (catalytic subunit and two cofactors, respectively) could be elucidated very similar to SARS-CoV. This may give an idea about a successful infection than SARS$\mathrm{CoV}$, perhaps explaining the increased ribonucleic acid (RNA) production. ${ }^{[14]}$
Scientists have discovered that high-density lipoprotein (HDL) scavenger receptor B type 1 (SR-B1) facilitates cellular SARS-CoV-2 entry linked to ACE-2 in a recent study. The study demonstrated that the S1 subunit of SARS-2-S binds to cholesterol and possibly HDL components to increase viral uptake in vitro. They stated that SR-B1 expression facilitated the entry of SARS-CoV- 2 into cells expressing ACE- 2 by enhancing the connecting of the virus to the cell surface. They noted that blocking the cholesterol-binding site on SARS-2-S1 or closing it with pharmacological SR-B1 antagonists could prevent HDL-enhanced SARS-CoV-2 infection. They also noted in their study findings that SR-B1 is co-expressed with ACE-2 in human pulmonary tissue and various extrapulmonary tissues. ${ }^{[16]}$

\section{Cellular Entry and Membrane Fusion}

The virus enters target cells by infecting via different entry patterns by droplet or contact. First, it passes through ACE-2, thanks to the $\mathrm{S}$ protein RBD, on the most accepted pathway. ${ }^{[16]}$ This entry also requires the $S$ protein cleavage by the transmembrane protease serine 2 (TMPRSS2). Thus, the fusion peptide located in the S2 domain can be released and dramatically increases the SARS-CoV-2 entry. ${ }^{[17]}$ Also, separation by cathepsin L can be performed during endocytosis. Differently, like the classical cleavage site known in the SARS-CoV S protein, SARS-CoV-2 S presents a furin-like cleavage site often observed in highly virulent influenza viruses. This can provide cleavage provided that formal integrity is maintained in the Golgi apparatus during biosynthesis and prolonged tropism and transmissibility due to the nearly ubiquitous furin-like protease. ${ }^{[18]}$ Although the accepted binding is ACE-2/RBD in the literature, a new entry route has been recently demonstrated via CD147 (Basigin), but we need more evidence. ${ }^{[19]}$

\section{In Vivo Interactions}

After the virus completes cell fusion and entry, viral proteins are released. Genomic RNA is then released, producing enzymes essential for the necessary viral protein synthesis, which is a process that requires ribosomal frameshift. ${ }^{[20]}$ The encoded polyprotein is processed to give 16 nsp, which combines to form the replicase-transcriptase complex. As a result, host viral membrane fusion and the RNA genome release into the host cell cytoplasm occurs. First, the host translation mechanism is captured for the translation of vital proteins and essential viral proteases. The polyproteins (pp1a and pp1ab) are cleaved by 3 CLpro and PLpro into 16 effector proteins, allowing the replication complex to be synthesized with RNA-dependent RNA polymerase that synthesizes a fulllength negative RNA chain template. In this way, both viral RNA to be copied and mRNAs that will synthesize proteins are created. The newly synthesized and viral structural and helper proteins are then sent from the ER to the Golgi apparatus, reminiscent of normal cellular glycoprotein synthesis. The new virions are assembled in budding Golgi vesicles. Finally, mature SARS-CoV-2 virions are released from the host cell into the surrounding environment to repeat the exocytosis infection cycle (Figure 3). ${ }^{[21,22]}$ 


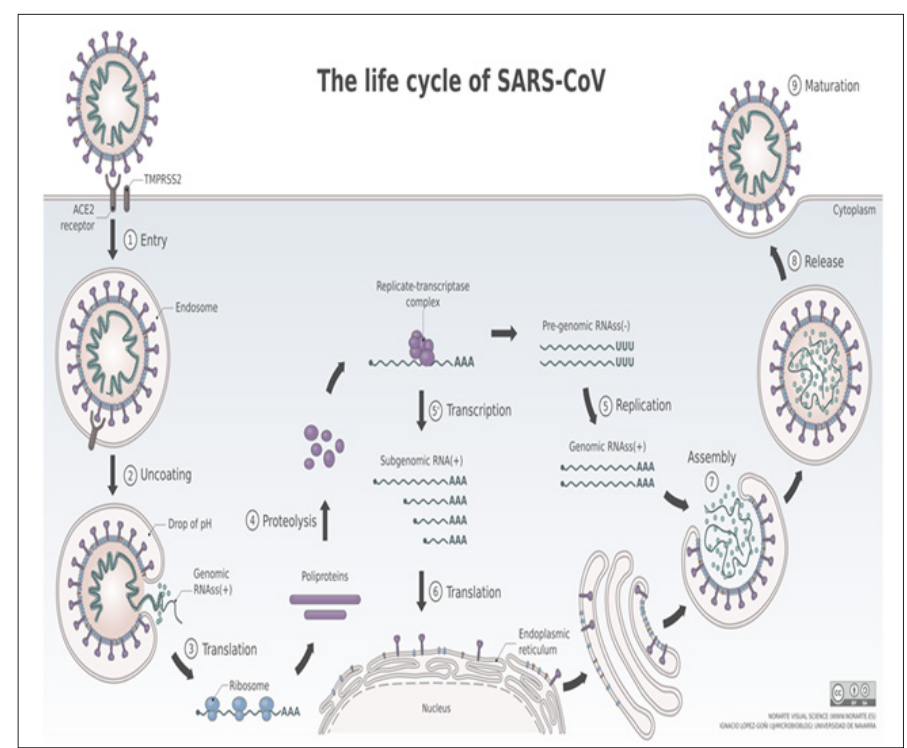

Figure 3. The SARS-CoV life cycle, which is very similar to SARS-CoV 2, can give us detailed information regarding COVID-19 disease. From SARS and MERS: recent insights into emerging coronaviruses. De Wit $E$, van Doremalen N, Falzarano D, Munster VJ. Nat Rev Microbiol. 2016 Aug;14(8):523-34. This file was licensed by the Creative Commons Attribution-Share Alike 4.0 International license. https://creativecommons.org/licenses/by-sa/4.0/deed.en

https://upload.wikimedia.org/wikipedia/commons/2/23/SARS-CoV-2_cycle.png

\section{New interactions discovered at ACE-2 level}

Recent data provide evidence that ACE-2 effectively scatters through membranes. This process is fine-tuned at different levels involving two cell membrane proteases: protein 17 (ADAM17) and transmembrane protease serine 2 (TMPRSS2), which contains the lytic and metalloproteinase domain. ${ }^{[23]}$ ADAM17 acts directly on ACE-2, causing it to be thrown into the intercellular space, while TMPRSS2 cleaves ACE- 2 and the $S$ protein of SARS-CoV-2, thus leading to membrane fusion and the entrance of the virus into the cell. As a result, while ADAM17 and TMPRSS2 both act on ACE-2, they can adversely affect net ACE-2 shedding. When the known proteolytic activities of ADAM17 and TMPRSS2 cause more ACE-2 shedding than internalization, it follows that this can create a natural barrier to infection. This may be due to the interaction between soluble ACE- 2 and the virus, located away from sensitive tissues. ${ }^{[24]}$

\section{Treatment trials and vaccine studies}

To date, treatment products are (25);

- Antibodies have been taken from the blood of people who have survived Covid-19 infection or neutralizing antibodies produced in the laboratory, antibodies to turn down the known catastrophic immune response of Covid-19 "cytokine storm".

- Antivirals to stop viruses from reproducing by blocking one or more steps in the process.

- Cell-based therapies such as transferring into patients' live cells to treat a specific disease. Different cell types taken from different tissues can be used for this purpose.
- Devices, such as blood purification devices, filter patients' blood to remove cytokines that cause a "cytokine storm" that can lead to respiratory or organ failure.

- RNA-based therapies stop viral replication by disrupting viral proteins' structure and blocking the virus's synthesis that invades our cells.

- Scanning compounds to repurpose (previously known and well-informed materials) can play a role in treatment.

- Other drugs include steroids, malarial drugs, cancer drugs, anti-immune-system drugs, etc.

To date (Figure 4), there are 237 vaccines are in development, 38 are now in clinical testing, and ten leading candidates are in the clinical phase three. ${ }^{[26]}$;

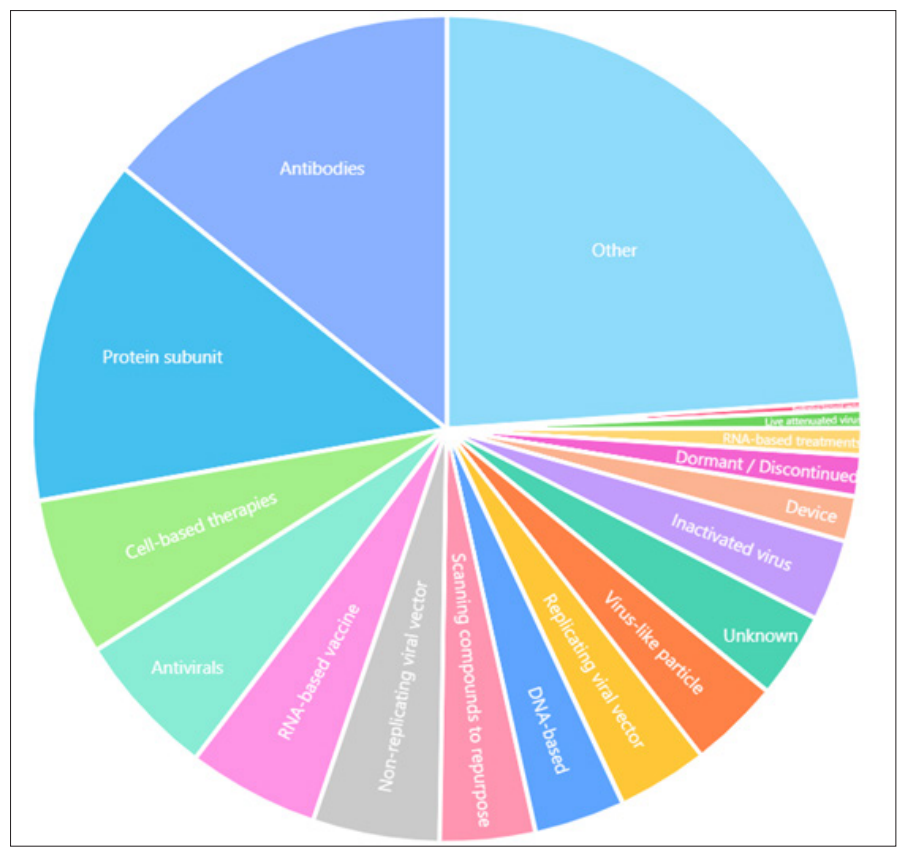

Figure 4. All COVID-19 treatment methods and vaccine candidates so far in Research Pipeline. Via 2020 Milken Institute. Achieved with Airtable membership.

https: / airtable.com/shrSAi6t 5 WF w q o $3 \mathrm{GM} / \mathrm{tb} / \mathrm{EzPQS} 5 \mathrm{fnc0FHYR}$ viwDBH7b6FjmIBX5x?blocks=bipZFzhJ7wHPv7x9z

- Live attenuated virus that must be able to reproduce (selfreplicate) and generate a robust immune response, but it must not make people sick.

- The deactivated virus is the killed version of the virus and is expected to generate an adequate immune response. They are preferred, especially in patients with immunodeficiency syndrome where attenuated vaccine cannot be used due to its side effects.

- Subunit vaccines (protein subunit or virus-like particles) use the virus's fragments, rather than the whole virus, to trigger an immune response inside the body.

- Nucleic Acid Vaccines or gene-based vaccines reflect a "state of the art" approach to vaccination. Compared to vaccines containing all or part of the virus, this ingenious method uses genetic engineering to deliver nucleic acids 
(DNA or RNA) that carry genetic instructions for viral protein synthesis to the target cell. After the nucleic acid pieces enter the cell, it synthesizes viral proteins that will trigger an immune response. Because these vaccines consist only of nucleic acids (DNA or RNA) and do not contain other viral parts, they are both easy to manufacture and safe.

- Viral Vector Vaccines are similar to nucleic acid vaccines in that they provide instructions for viral protein production. However, instead of using plasmids or lipids to introduce them into the cell, these vaccines use attenuated viruses (vector virus) other than the virus that caused the disease to carry the viral genes' blueprint.

\section{Extreme ideas for tough times}

As the world approaches after Covid-19 vaccine studies, we still do not have a cure, and it is not yet luminous to what extent and in what variety vaccines will be offered to the service of all humanity. Since we are faced with a virus that affects the whole world and is transmitted by air-droplets, it has been necessary to limit this pathogen's effects to return to everyday life almost everywhere in the world. Mosquitoes modified with gene drive systems control infectious diseases by reducing the targeted number of disease carriers (population suppression) or reducing their ability to transmit the pathogen to humans (population change/modification). Gene driver systems provide preferential (super-mendelian) inheritance of genetic traits included in hybridizing mosquito populations. These systems can be self-limiting when limiting impacts are desired or provide continuity when the features are intended to spread across the local population. The impact is planned to be permanent. ${ }^{[27]}$ It may not be an acceptable idea, but it can be released into the environment by producing a genetically modified SARS-CoV-2 virus with inactivated selected genes, with higher binding affinity with ACE-2 and TMPRSS2, and will not cause disease. At this point, if genetically modified SARS-CoV-2 is to be used, genetic engineering should work so fine-tuned that the genetically driven virus should perform the intracellular stages detailed so far as a one-to-one active pathogen and enter a kind of competitive inhibition with the real SARS-CoV-2. Differently, a different agent with the same protein-binding sites containing similar tissue tropism can also be used. This approach's main idea is that the nonpathogenic agent provides social immunity, rather than the attenuated virus, through the transmission like Oral Polio Virus (OPV) vaccine. If the produced genetically modified nonpathogenic virus is successful, it can be applied primarily in communal living areas to breathe at critical points of life. This idea is only a theory, but it should not be forgotten that no one even predicted the point reached in the pandemic.

\section{CONCLUSION}

Being able to illuminate the nature of the virus is essential to develop treatments that can remedy humanity. Besides, it is vital to understand the microscopic structuring in order to obtain effective efficiency from vaccines and to act by predicting possible mutations. Although the light was seen at the end of the tunnel, the massive blow to the world and humanity due to Covid-19 is obvious. Just as the virus attacks us with all its might, we have to attack everything we have. Vaccines, medicines, supportive care, masks, social distance, etc. We hope that humanity will take care of this scourge by turning to science entirely and transparently.

\section{ETHICAL DECLARATIONS}

Referee Evaluation Process: Externally peer-reviewed.

Conflict of Interest Statement: The authors have no conflicts of interest to declare.

Financial Disclosure: The authors declared that this study has received no financial support.

Author Contributions: All of the authors declare that they have all participated in the design, execution, and analysis of the paper, and that they have approved the final version.

\section{REFERENCES}

1. Paules $\mathrm{Cl}$, Marston HD, Fauci AS. Coronavirus infections-more than just the common cold. JAMA. 2020 Feb;323(8):707-8.

2. Walsh EE, Shin JH, Falsey AR. Clinical impact of human coronaviruses $229 \mathrm{E}$ and OC43 infection in diverse adult populations. J Infect Dis. 2013 Nov;208(10):1634-42.

3. Zhou P, Yang XL, Wang XG, Hu B, Zhang L, Zhang W, et al. A pneumonia outbreak associated with a new coronavirus of probable bat origin. Nature. 2020 Mar;579(7798):270-3.

4. Mousavizadeh L, Ghasemi S. Genotype and phenotype of Covid-19: their roles in pathogenesis. J Microbiol Immunol Infect. 2020 Mar; S16841182(20)30082-7. https://doi.org/10.1016/j.jmii.2020.03.022.

5. Gorbalenya AE, Baker SC, Baric R.S.; Coronaviridae Study Group of the International Committee on Taxonomy of Viruses. The species Severe acute respiratory syndrome-related coronavirus: classifying 2019-nCoV and naming it SARS-CoV-2. Nat Microbiol. 2020 Apr;5(4):536-44.

6. Hoffmann M, Kleine-Weber H, Schroeder S, Krüger N, Herrler T, Erichsen S, et al.SARS-CoV-2 cell entry depends on ACE-2 and TMPRSS2 and is blocked by a clinically proven protease inhibitor. Cell. 2020 Apr;181(2):271-280.e8.

7. Matsuyama S, Nagata N, Shirato K, Kawase M, Takeda M, Taguchi F Efficient activation of the severe acute respiratory syndrome coronavirus spike protein by the transmembrane protease TMPRSS2. J Virol. 2010 Dec;84(24):12658-64.

8. Shang J,Wan Y, Luo C, Ye G, Geng Q, Auerbach A, et al. Cell entry mechanisms of SARS-CoV-2. Proc Natl Acad Sci USA. 2020 May;117(21):11727-34.

9. Ou X, Liu Y, Lei X, Li P, Mi D, Ren L, et al. Characterization of spike glycoprotein of SARS-CoV-2 on virus entry and its immune cross-reactivity with SARS-CoV. Nat Commun. 2020 Mar;11(1):1620.

10. Millet, J. K. \& Whittaker, G. R. Physiological and molecular triggers for SARS-CoV membrane fusion and entry into host cells. Virology 517, 3-8 (2018). Return to ref 17 in the article.

11. de Haan CA, Haijema BJ, Schellen P, Wichgers Schreur $P$, te Lintelo $E$ Vennema $\mathrm{H}$, et al. Cleavage of group 1 coronavirus spike proteins: how furin cleavage is traded off against heparan sulfate binding upon cell culture adaptation. J Virol. 2008 Jun;82(12):6078-83.

12. Cagno V, Tseligka ED, Jones ST, Tapparel C. Heparan sulfate proteoglycans, and viral attachment: proper receptors or adaptation Bias? Viruses. 2020;11(7):596.

13. Milewska A, Zarebski M, Nowak P, Stozek K, Potempa J, Pyrc K. Human coronavirus NL63 utilizes heparan sulfate proteoglycans for attachment to target cells. J Virol. 2014 Nov;88(22):13221-30. 
14. Peng Q, Peng R, Yuan B, Zhao J, Wang M, Wang X, et al. Structural and biochemical Characterization of nsp12-nsp7-nsp8 core polymerase complex from Covid-19 virus. Cell Rep. 2020 Jun;31(11):107774.

15. Wei C, Wan L, Yan Q, Wang X, Zhang J, Yang X, et al. HDL-scavenger receptor $B$ type 1 facilitates SARS-CoV-2 entry. Nat Metab. 2020 Nov; https://doi.org/10.1038/s42255-020-00324-0.

16. Letko $M$, Marzi $A$, Munster V. Functional assessment of cell entry and receptor usage for SARS-CoV-2 and other lineage $B$ beta coronaviruses. Nat Microbiol. 2020 Apr;5(4):562-9.

17. Tai W, He L, Zhang X, Pu J, Voronin D, Jiang S, et al. Characterization of the receptor-binding domain (RBD) of 2019 novel coronavirus: implication for the development of RBD protein as a viral attachment inhibitor and vaccine. Cell Mol Immunol. 2020 Jun;17(6):613-20.

18. Walls AC, Park YJ, Tortorici MA, Wall A, McGuire AT, Veesler D. Structure, Function, and Antigenicity of the SARS-CoV-2 Spike Glycoprotein. Cell. 2020 Apr;181(2):281-292.e6.

19. Wang K, Chen W, Zhou YS, Lian JQ, Zhang Z, Du P, et al. SARS-CoV-2 invades host cells via a novel route: CD147-spike protein. Microbiology. 2020.

20. Baranov PV, Henderson CM, Anderson CB, Gesteland RF, Atkins JF, Howard MT. Programmed ribosomal frameshifting in decoding the SARS-CoV genome. Virology. 2005 Feb;332(2):498-510.

21. Guo YR, Cao QD, Hong ZS, Tan YY, Chen SD, Jin HJ, et al. The origin, transmission and clinical therapies on coronavirus disease 2019 (Covid-19) outbreak - an update on the status. Mil Med Res. 2020 Mar;7(1):11.

22. Fehr AR, Perlman S. Coronaviruses: an overview of their replication and pathogenesis. Methods Mol Biol. 2015;1282:1-23.

23. Heurich A, Hofmann-Winkler H, Gierer S, Liepold T, Jahn O, Pöhlmann S. TMPRSS2, and ADAM17 cleave ACE-2 differentially, and the only proteolysis by TMPRSS2 augments entry driven by the severe acute respiratory syndrome coronavirus spike protein. J Virol. 2014 Jan;88(2):1293-307.

24. Chen J, Jiang Q, Xia X, Liu K, Yu Z, Tao W, et al. Individual variation of the SARS-CoV-2 receptor ACE-2 gene expression and regulation. Aging Cell. 2020 Jul;19(7):192020030191.

25. Milken Institute. Covid-19 treatment and vaccine tracker. Glossary. https://covid-19tracker.milkeninstitute.org/glossary

26. Milken Institute. Covid-19 vaccine tracker. Last updated: November 30 , 2020, 2:33 PM PST. https://www.covid-19vaccinetracker.org/

27. World Health Organization. Guidance framework for testing of genetically modified mosquitoes. 2014a. Available at http://apps.who.int/iris/ bitstream/10665/127889/1/9789241507486_eng.pdf?ua=1 Accessed December 16, 2019. Google Scholar. 